DOI: https://doi.org/10.34069/AI/2021.46.10.16 How to Cite:

Vasylevych, V., Obrusna, S., Iskenderov, E., Kryzhna, L., \& Sokurenko, O. (2021). Foreign experience in bullying prevention in schools. Amazonia Investiga, 10(46), 169-175. https://doi.org/10.34069/AI/2021.46.10.16

\title{
Foreign experience in bullying prevention in schools
}

\section{Зарубіжний досвід профілактики булінгу у школах}

Received: September 10, 2021

\begin{abstract}
The aim of the article is to conduct a comprehensive study of bullying prevention at schools using foreign experience. The subject of research is the concept of bulling and features of its manifestation in educational institutions. The research methodology includes general scientific and special methods of legal science: method of theoretical analysis and systematization of scientific literature, method of modeling, statistical method, dogmatic method, logical method, method of summarization. Research results. The main causes, consequences of bullying in schools are analyzed and the characteristics of its participants are given. It is determined that bullying can be considered as a social, legal, psychological and pedagogical problem. Practical meaning. It is proved that schools without bullying differ in cohesion and various extracurricular forms of interaction between students. Value / originality. It is stated that the main means of counteracting this negative phenomenon in educational institutions are active public life, an atmosphere of openness, the possibility of collective conflict resolution under the guidance of a caring teacher.
\end{abstract}

Accepted: October 30, 2021

Written by:

Vasylevych Vitaliii ${ }^{1}$

https://orcid.org/0000-0001-9351-4219

Obrusna Svitlana ${ }^{62}$

https://orcid.org/0000-0001-9354-9235

Iskenderov Elchin ${ }^{63}$

https://orcid.org/0000-0002-9622-7984

Kryzhna Liudmyla ${ }^{64}$

https://orcid.org/0000-0003-2397-322X

Sokurenko Oleksandr ${ }^{65}$

https://orcid.org/0000-0002-8500-948X

\footnotetext{
${ }^{61}$ Doctor of Law, Professor, Scientific Secretary of the Scientific Council Secretariat of the National Academy of Internal Affairs, Ukraine.

${ }^{62}$ Doctor of Law, Associate Professor, Professor of the Department of State and Legal Disciplines of Bohdan Khmelnytsky National University of Cherkasy, Ukraine.

${ }^{63}$ Doctor of Law, Professor of the Department of the Interregional Academy of Personnel Management, Ukraine.

${ }^{64} \mathrm{PhD}$ in Law, Associate Professor, Associate Professor of the Department of Criminology and Penal Law of the National Academy of Internal Affairs, Ukraine.

${ }^{65} \mathrm{PhD}$ in Law, Associate Professor, Associate Professor of the Department of the Department of State and Legal Disciplines of Bohdan Khmelnytsky National University of Cherkasy, Ukraine.
} 
Keywords: bullying, forms of bullying, bullying prevention, causes of bullying, bullying participants. атмосфера відкритості, можливість колективного вирішення конфліктів під керівництвом небайдужого педагога.

Ключові слова: булінг, форми булінгу, профілактика булінгу, причини булінгу, учасники булінгу.

\section{Introduction}

The national strategy in the area of human rights is aimed at improving the activities of the State to ensure human rights and freedoms, creating an effective mechanism for their protection, solving systemic problems in this area. One of its directions is to ensure the functioning of a safe educational environment in educational institutions, in particular effective mechanisms to prevent and combat bullying of participants in the educational process (Order of the President of Ukraine No. 119/2021).

Bullying at school is a widespread phenomenon, especially in primary school, where it has various manifestations. In addition to bullying among schoolchildren, bullying by teachers in relation to schoolchildren also occurs, and vice versa. There is also bullying among teachers themselves.

Everyone is involved in bullying as aggressors, victims, observers. Bullying affects various areas of school life: the sense of security of students and teachers, physical and psychological health, quality and efficiency, the culture of school life in general. Therefore, this issue requires significant research.

Thus, the purpose of the article is a comprehensive research of bullying prevention at schools using foreign experience.

\section{Methodology}

The following methods are used to implement the tasks set in the work.

The method of theoretical analysis and systematization of scientific literature on the topic of research is applied for comparison, generalization of theoretical and experimental data on the issue presented in the psychological literature.

The method of modeling helps in the construction and analysis of a theoretical model of emotional intelligence of bullying participants in the school environment.
Statistical method makes it possible to analyze the data on the problem under consideration.

With the help of dogmatic method the concept of bullying is examined and its features are outlined.

Logical method is used for providing characteristics of bullying participants (bully, victim, witnesses).

The method of summarization helps to draw relevant conclusions.

\section{Literature Review}

In 2014, the Centers for Disease Control and Department of Education (Stopbullying.gov, 2021a) released the first federal definition of bullying. The definition includes three core elements:

- unwanted aggressive behavior

- observed or perceived power imbalance

- repetition or high likelihood of repetition of bullying behaviors.

Sampson (2009) proves that there are 2 core factors of bullying: detrimental actions, which constantly repeat, and an imbalance of power between the bully and the victim.

Menesini and Salmivalli (2017) allocate 3 reference points to consider aggressive behaviour as bullying: (1) repetition, (2) intentionality and (3) an imbalance of power.

Papanikolaou, Chatzikosma, and Kleio (2011) believe that it is the lack of parent's involvement in educational process of their children that cause bullying in school. In occurs, when parents punish their children without justification, or when they do not apply sanctions even when children deserve punishment.

Colino et al., (2021) stress that bullying can exist in many forms: it can be bodily (strikes, attacks); oral (threatening, giving nicknames); or mental (ignoring, telling stories, etc). Besides, 


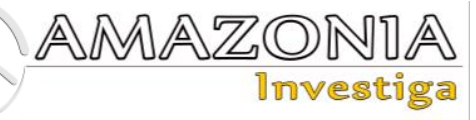

cyberbulling (bullying through social networks or messengers) is also widerspread and traumatic for the child.

Al-Ali and Shattnawi (2018) state that this phenomenon negatively affects both the victim and the bully. Victims complaine of a huge number of psychosomatic diseases connected with bullying: depression; sleep problems; nightmares; headache, etc. Besides, there are suicidal tendencies both in behavior of victims and bullies.

In order to overcome this negative phenomenon Divecha (2019) proposes to: build positive school climate, apply social and emotional learning, take into account individual differences between children, involve parents.

Rosenkrantz (2021), in her turn, suggests to: diagnose the problem, create an intervention plan, encourage peer support, model proper behavior.

The lecturers of Lesley University (2016) propose the following ways to combat bullying in educational institutions: to teach students kindness and empathy; create for them opportunities for connection; identify "gateway behaviors"; use the arts to create context; minimize "concentric circles" in schools; participate in simulations.

\section{Results and Discussion}

The problem of bullying for various reasons is ignored by adults (educators, teaching staff), who, caring for their own reputation and the reputation of the school, ignore this problem. Parents often do not consider it a problem at all, or, worrying about their children, transfer them to another school, institution or isolate them from society. It is not uncommon for teachers themselves to be involved in the bullying process, where they can act as initiators or even aggressors, as they consider bullying a convenient means of collective disciplinary action, as a result of which the problem becomes more widespread and violent. Recently, violence has also affected teachers, who are the victims, who become the victims of bullying by inadequate responsive pupils and their parents.

At the first glance, bullying is a separate phenomenon in the area of educational psychology. However, this term originated first in the study of adult groups. Apparently, bullying is developing in almost any closed community whether it be an army unit or an elite college, and the fact that children are regularly exposed to bullying at school is just an example of its prevalence. Having been working on this topic for many years, the Norwegian psychologist Dan Olweus (1993) presented a common definition of bullying among children and adolescents; according to him bullying is a deliberately systematically repeated aggressive behavior, including inequality of social or physical power.

His work brought the phenomenon of bullying into the space of psychological science, made it visible, and this topic quickly became a trend in world psychology, research into phenomenology and bullying prevention and control technologies began to develop rapidly. Their relevance is very high due to the heavy impact of bullying on its participants, up to suicide.

A specific problem in the current situation, both in the world and in Ukraine, is the manifestation of bullying against teachers. In our opinion, the aggressive attitude of adolescents towards the teacher is associated with the desire to enhance the credibility in the eyes of classmates. On the positive side, it can be noted that most teachers face bullying just two or three times, and only in some cases are bullied by students regularly.

Bullying by students against teachers is most frequent as follows:

1. Students tease the teacher, come up with nicknames, ignore him (her).

2. Show contempt with gestures.

3. Discuss his (her) personal life.

4. Systematically violate discipline.

5. Refuse to comply with the requirements.

When confronted with bullying from students, teachers do not always talk about it. Such situations can be perceived by teachers as their own incompetence, and they are ashamed to tell the colleagues and administration about it. It is very important to make it clear to the pedagogical community of the school that the administration is ready to become involved in their problems, to deal with them. In each particular case, the following points are of principle: support for colleagues and parental involvement. The school should have a common position on the inadmissibility of bullying in relation to children or teachers.

The National Association of School Workers (Selekman \& Vessey, 2004) has defined bullying as dynamic and repetitive patterns of verbal and / or non-verbal behavior developed by one or 
more students in relation to another one, with intent to cause harm intentionally, and there is a real or apparent difference in force.

Lane (1989) describes the "bullying structure" as a social system that includes persecutors, their victims and by-standers. Each participant has his own opinion about what is happening. Recently, the position of involuntary witnesses of bullying has attracted special attention of researchers. These witnesses are not subject to direct aggression, but because of their sense of helplessness, their self-esteem drops sharply.

The recent studies have proven that bullying is best regarded as a social phenomenon that includes more than just victims and aggressors, but also other participants (Cowie \& Berdondini, 2001). Children who bully others enjoy power and high status; therefore, aggressors have problems with the development of empathy towards other people, which may lead to criminal and deviant behavior.

It is advisable to distinguish the following types of bullying:

direct (both physical and verbal);

indirect (social deprivation, gossip, conspiracy, etc.).

To better understand the individual psychological characteristics of bullies, it is necessary to understand what positions they occupy and what roles they play. There are several classifications of roles in bullying. The most logical classification is proposed by Smith and Ananiadou (2003): initiator (persecutor), assistant initiator (seeks to help and imitate the persecutor), defender of the victim (usually defenders have the greatest authority among classmates), victim and observers.

The issue of stability of roles in bullying was studied separately. Sourander et al., (2000) conducted longitudinal study showing that after eight years, in a repeated cut, $11 \%$ of the aggressors and and $12 \%$ of victims retained their positions in the classroom. According to other data, up to half of the bullying participants played the same roles 4 years later. Kon (2006) came to the conclusion that the stability of the role depends on the structure of the class: the more rigid it is, the more difficult it is for the student to lose his role.

In the case of bullying by a teacher against a student, the following consequences may arise:
- the student avoids school under any pretext;

- the student does not want to talk about school affairs and what is happening in life in general;

- psycho-emotional changes in the student's behavior (anxiety, aggression, isolation, depression);

- the student is characterized by a higher frequency of diseases (psychosomatic comes in for fear of teachers, which can be manifested by headaches, diseases of the gastrointestinal tract, dermatological problems);

- the student begins to spend more time in cyberspace and less with friends;

- hides information about success (conceals information about academic performance (alternatively, one subject falls sharply);

- there is self-destructive behaviour and a sharp drop in the child's self-esteem.

If one notices one or more of the above processes, it indicates that there are serious problems at school, which cannot be deal with by the child without the parents' help.

A high percentage of bullying is in Asian countries (because of the mentality: people prefer to ignore the problem), in the United States (because of the country's multiculturalism the same methods of struggle do not work for different nationalities), in post-Soviet countries (due to outdated Soviet approaches to education, which still exist in many regions).

There is a very high percentage of bullying in Japanese schools; notably that the teachers are often aggressors. In 2013 the law that requires schools to report bullying was passed. However, the introduction of the "STOPit" mobile application, thanks to which students can report cases of bullying, works more successful in this area.

The schools in Canada move away from the socalled "zero tolerance" principle in anti-bullying matters. The latter lies in severe sanctions against bullies (suspension / expulsion from school) (Olweus, 1993, p. 1). It is a common practice to conduct practical classes, to which guest experts (psychologists, social workers, police officers who cooperate with the school) are invited. Such classes are devoted to acquaintance with the legislation, which defines the rules of behavior for teenagers (Olweus \& Limber, 2010).

Much attention is also paid to the dissemination of interactive anti-bullying resources: materials for students, teachers and parents are posted on 


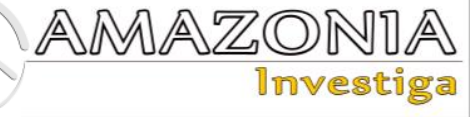

the official websites of schools; the interior of the classroom is decorated with anti-bullying posters, wall newspapers, postcards. To monitor the problem of bullying at school, regular surveys are conducted among students, their parents and teachers; a journal is kept to record the number of cases and applications received from parents; the situation is discussed at teachers' and parent meetings (Kostiuk, 2015, p. 34).

Each state of the USA has its own law governing bullying in schools, which compensates for the lack of federal law in this area. Besides, when it is not necessary to create many official antibullying programs, one can just include some of their components in everyday training. That is, each lesson should directly or indirectly address the issue of bullying, fostering tolerance and respect in the team: it is either a lesson with a specialized topic about bullying and its consequences or interactive that help students feel in a single team (Stopbullying.gov, 2021b).

Installation of surveillance cameras was the main action taken by the school administration to solve the problem of bullying in Greece (Roberge, 2012 , p. 1). In our opinion, the developed State strategy of the Scandinavian countries to combat bullying deserves special attention. Sweden is a very progressive State in the matters of combating bullying, as in 2006 it has adopted clear legislative strategy to prevent this negative phenomenon.

According to this strategy, all preschools and schools are responsible for combating child bullying. When teachers learn that children have been abused, they should investigate the cases and work to resolve the problems to prevent recurrence of bullying.

Besides, the office of Ombudsman for Child and Student Protection (BEO) has been introduced in Sweden as part of the Swedish School Inspectorate, which is a separate organization from the Ombudsman for Children in Sweden (Barnombudsmannen). BEO is the agency that oversees the implication of the Law on Education on Bullying in Schools and Preschools. Parents and children can inform BEO about cases of bullying in these establishments (Salmivalli, Kärnä \& Poskiparta, p.133).

The Finnish Basic Education Act of 1999 stipulates that every student has the right to safe school environment, and that teachers are responsible for ensuring that students are not abused or bullied at school. In 2003, the law was amended; now it obliges educational institutions to draw up plans to protect students from violence, bullying and harassment (Trach, 2010, p. 405).

Despite all these measures, the percentage of bullying victims continued to rise, and since then an anti-bullying programme $\mathrm{KiVa}$ has been developed. The program includes general actions (lessons on a given topic, guide for parents, information posters) and virtual trainings (antibullying computer games for elementary school students, Internet Forum "KiVa Street" for high school students).

KiVa's key task is training of witnesses of bullying, who try to evoke sympathy for victims of bullying. The Norwegian anti-bullying campaign is called "Zero" and it provides a rather unconventional approach to combating bullying. In particular, each school creates a special council, which includes several teachers, parents, students, and it is headed by the school principal. Such a different composition of representatives, according to the authorities, should provide the most comprehensive approach to preventing and detecting cases of bullying (Trach, 2010, p. 744).

Therefore, the legal policy of the State in combating bullying should be aimed not only at the adoption of legislation that would establish responsibility for bullying, and oblige the school administration to conduct appropriate investigations. The State should develop the strategy to combat bullying, and therefore needs to implement anti-bullying programs, which are successful in many countries. Thus, it is necessary, firstly, to consider the fight against bullying one of the areas of State policy in the field of human rights. Secondly, there is a need to develop a universal plan of preventive measures for educational institutions, on the basis of which schools and other educational institutions will draw up their plans and report on its implementation.

In general, there are three main approaches to the study of bullying. The first one is focused on the individual characteristics of bullying participants, intrapersonal preconditions that contribute to the fact that the child is a victim or aggressor.

Unevenness of life-course risks is studied and the existence of life events, in the course of which the child's vulnerability, as well as the risk of mastering the role of aggressor or victim in bullying situations increases, is described within the second approach. 
The third approach emphasizes the role of the environment, group microclimate and systemic processes in the community, in which the dominant way of interaction between people is a way based on inequality of power: the context actualizes intrapersonal preconditions and converts bullying from risk to reality.

These approaches differ in terms of the targets of psychological work aimed at ceasing bullying situations. Within the dispositional approach, the target is the development of certain skills and qualities in the victim (primarily self-confidence and communication skills) and the bully (development of tolerance). Temporal approach involves psychological support of children during age crises and difficult life situations and the development of children's resilience and ability to use available socio-psychological resources.

As a systemic phenomenon, bullying fulfils the task of establishing and maintaining a social hierarchy: the bully thus maintains his (her) status and degrades the status of the victim, and witnesses use this process to find their place in the hierarchy. Therefore, in the contextual approach, the target is to change the system of relations within the group or organization as a whole - the formation of an alternative method of determining status in the group, where power differs and the value of respectful relationships are important. This approach is more promising in terms of long-term effect.

\section{Conclusion}

Thus, we tried to describe the main directions and results of bullying research. There is a serious shortage of such research in Ukraine. Obviously, there is a need to study this topic, which is related, on the one hand, to the general negative experience of being an oppressed victim and the inability to resist the bearer of power, and on the other one - to the habit of this mode of communication and the difficulty of choosing alternative practices. We have shown different social levels and systems in which bullying behavior can be practiced. The discourse of coercion and violence is not born in a particular family or school; there are layers of politics and culture behind it, and you have to remember that these layers are interconnected.

In order to detect cases of masked violence and reduce bullying in a particular institution, the dominant and marginalized discourse of power in the community needs to be studied. Only by taking clear moral stand and reflecting ideas of respondents and researchers on the treatment of authority, it is possible to consistently deploy communication strategies alternative to those based on inequalities in status and power.

Summing up the analysis, we concluded that the procedure for monitoring the prevalence of bullying in an educational institution requires some training and guidance from specialists. Under such conditions, monitoring is feasible and can provide a realistic picture of the schools in the region and the classes of one school.

Disguised, unnoticed bullying leads to severe consequences for the school, at the very last resort - to adolescent suicide; it also destroys creative school atmosphere aimed at developing and the credibility of the school as such. An important fact: classes without bullying are cohesive with various extracurricular forms of interaction between students. Active public life, as well as the atmosphere of transparency, the opportunity to resolve conflicts under the guidance of a caring teacher - all this is the antidote to this negative phenomenon. However, we must not forget that bullying can take place even in the best class or school, as the bully is the child with serious emotional disorders, which in some cases are not noticeable to an inattentive eye.

\section{Bibliographic References}

Al-Ali, N. and Shattnawi, K. (March 21st 2018). Bullying in School, Health and Academic Achievement, Blandina Bernal-Morales, IntechOpen, DOI: 10.5772/intechopen.75729. Available from: https://www.intechopen.com/chapters/60102 https://www.intechopen.com/chapters/60102

Colino, S., Broadwell, L., Schuman, C., \& Peck, S. (2021). How to Deal With Bullies: A Guide for Parents. Parent's Magazine. https://www.parents.com/kids/problems/bull ying/bully-proof-your-child-how-to-dealwith-bullies/

Cowie, H., and Berdondini, L. (2001). Children's reaction to cooperative group work: a strategy for enhancing peer relationships among bullies, victims and bystanders. Learning and Instruction, No. 11, pp. 517-530.

Divecha, D. (2019). What Are the Best Ways to Prevent Bullying in Schools? Greater Good Magazine https://greatergood.berkeley.edu/article/item/ what_are_the_best_ways_to_prevent_bullyi ng_in_schools

Kon, I. (2006). What is bullying and how to fight with it? Family and School, No. 11, 


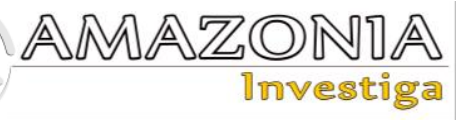

pp. http://valery-

159.narod.ru/mnd/bullying_kon.htm

Kostiuk, O. (2015). Canadian experience in antibullying work in high school. Comparative and pedagogical studies, No. 26, pp. 28-35. https://docplayer.net/83859369Dosvid-kanadi-shchodo-antibulingovoyiroboti-v-seredniy-shkoli-olga-kostyuk.html

Lane, D. A. (1989). Bullying in School: The Need for an Integrated Approach. School Psychology International, 10(3), pp. 211215, https://doi.org/10.1177/0143034389103 007

Lesley University (2016). 6 Ways Educators Can Prevent Bullying in Schools. https://lesley.edu/article/6-ways-educatorscan-prevent-bullying-in-schools

Menesini, E. \& Salmivalli, C. (2017). Bullying in schools: the state of knowledge and effective interventions. Psychology, Health \& Medicine, No. 22, pp. 240253, DOI: $10.1080 / 13548506.2017 .1279740$

Olweus, D. (1993). Bullying at school: What we know and what we can do. Hoboken: WileyBlackwell.

https://books.google.com.ua/books?id=0Fz1j D9paoQC\&printsec $=$ frontcover $\& \mathrm{hl}=\mathrm{ru} \# \mathrm{v}=\mathrm{O}$ nepage \&q\&f=false

Olweus, D., and Limber, S. P. (2010). The Olweus Bullying Prevention Program: Implementation and evaluation over two decades. In S. R. Jimerson, S. M. Swearer, \& D. L. Espelage (Eds.), Handbook of bullying in schools: An international perspective (pp. 377-401). Routledge/Taylor \& Francis Group.

Order of the President of Ukraine No. 119/2021. On the adoption of the National Strategy in the area of human rights. Official Representative Office of the President of Ukraine, March 24, 2021. https://www.president.gov.ua/documents/11 92021-37537

Papanikolaou, M., Chatzikosma, T., and Kleio, K. (2011). Bullying at School: The role of family. Procedia - Social and Behavioral Sciences, Vol. 29, pp. 433-442, https://doi.org/10.1016/j.sbspro.2011.11.260

Roberge, G. D. (2012). From zero tolerance to early intervention: The evolution of school anti-bullying policy. (PDF) https://in.nau.edu/wpcontent/uploads/sites/135/2018/08/FromZero-Tolerance-to-Early-Intervention-ek.pdf

Rosenkrantz, H. (2021). How to Handle Bullying at School. About U.S. News https://www.usnews.com/education/k12/arti cles/how-to-handle-bullying-at-school

Sampson, R. (2009). Bullying in Schools. Problem-Oriented Guides for Police Problem-Specific Guides Series, No. 12. https://www.ojp.gov/ncjrs/virtuallibrary/abstracts/bullying-schools-1

Salmivalli, Ch., Kärnä, A., and Poskiparta, E. (2011). Counteracting bullying in Finland: The KiVa program and its effect on different forms of being bullied. International Journal of Behavioral Development, 35(5), pp. 405-411. doi: $10.1177 / 0165025411407457$.

Smith, P., and Ananiadou, K. (2003). The Nature of Bullying and the Effectiveness of SchoolBased Interventions. Journal of Applied Psychoanalytic Studies, 5(2), pp. 189-209.

Sourander, A., Helstela L., Helenius H., and Piha J. (2000). Persistence of bullying from childhood to adolescence - a longitudinal 8year follow-up study. Child Abuse and Neglect, 24(27), pp. 873-881.

Selekman, J., and Vessey, J. (2004). Bullying: It Isn't What It Used To Be. Pediatric Nursing, 30(3), pp. $246-249$.

Stopbullying.gov (a federal government website managed by the U.S. Department of Health and Human Services (2021a)). Facts About Bullying.

https://www.stopbullying.gov/resources/fact $\mathrm{s}$

Stopbullying.gov (a federal government website managed by the U.S. Department of Health and Human Services (2021b)). Prevention at school.

https://www.stopbullying.gov/prevention/atschool/index.html

Trach, J., Hymel, S., Waterhouse, T. \& Neale, K. (2010). Bystander Responses to School Bullying: A Cross-Sectional Investigation of Grade and Sex Differences. Canadian Journal of School Psychology, No. 25, pp. 114 - 130. doi: $10.1177 / 0829573509357553$.

Vaganova, O., Rudenko, I., Markova, S., Smirnova, Z., \& Kutepov, M. (2019). The use of educational video materials in educational process of a higher educational institution. Amazonia Investiga, 8(22), 216-222. Retrieved from https://amazoniainvestiga.info/index.php/ama zonia/article/view/308 